SHS Web of Conferences 10, 00018 (2014)

DOI: $10.1051 /$ shsconf $/ 20141000018$

C Owned by the authors, published by EDP Sciences, 2014

\title{
Prevention of corruption in the sphere of public purchases: Interviews with experts
}

\author{
A. Krivins \\ Rīga Stradiņš University, Latvia
}

\begin{abstract}
Corruption is a very acute problem in the sphere of the public procurement. Considering that standard approach to this problem (e.g. severe sanctions or addition to a salary) does not lead to positive results in the long-term, non standard solutions for reduction of corruption regarding the personality of the corrupted official should be found (Krivinsh, 2012a). Having agreed that the corruption is a phenomenon that is determined by several conditions, such as historical, economic, social, normative, psychological etc., the main focus of attention of the author within the present article is directed towards the level of development of standard regulation of public purchases. The results of the research can be used both by specialists of the anticorruption institutions and procurement practitioners.
\end{abstract}

\section{Introduction}

This article is devoted to the topic of reduction of corrupt practices in the sphere of public procurement. The topicality of the topic is grounded by the author on the surveys of citizens of the EU countries and international indexes - Corruption Perceptions Index (CPI), Global Corruption Barometer (GCB), Bribe Payers Index (BPI), Global Corruption Report (GCR), National Integrity System assessments (NIS), Ease of doing business index, Global Integrity Report, Global Competitiveness Report, International Country Risk Guide (ICRG). Public procurement is an area particularly sensitive to corruption and it cannot be viewed separately from the overall context of corruption level. The corruption cases that came to light during last year's (e.g. Daimler AG, Siemens AG, Johnson \& Johnson, INNOSPEC INC, BAE (Krivinsh, 2012b), confirm this thesis.

\section{Materials and methods}

One of the methods applied in the framework of the doctoral thesis in order to detect the level of corruption in the sphere of public procurement was the qualitative research method - extended structural interviews with experts. The objective of the structural interviews was to obtain information on experience of representatives of specific groups, i.e. - to find out the opinion of various subjects related to public procurements (commissioning parties, the Public Procurement Monitoring Bureau, the Corruption Prevention and Combating Bureau, the State Police of Latvia, entrepreneurs, researchers

This is an Open Access article distributed under the terms of the Creative Commons Attribution License 4.0, which permits unrestricted use, distribution, and reproduction in any medium, provided the original work is properly cited. 


\section{SHS Web of Conferences}

who study the issue of corruption, the State Audit Office of the Republic of Latvia, legislators, public procurement executors) concerning the problem of corruption in the sphere of public procurement.

The same questions regarding the problem of corruption, and additional questions when needed, were asked to 10 experts; the answers were carefully recorded (data are obtained in 2012). Substantiation for the choice of experts: experts with rich experience (from 7 till 20 years) - highly skilled professionals in the field of their activity were asked to participate in the interviews.

\section{Results}

The following judgements of the experts were received as an answer to the question - What kind of violations takes place in public procurements and what is the frequency of their occurrence?:

Entrepreneur I.S. holds a view that deliberate or unintentional violations of public procurement procedures take place every day. As a result the honest entrepreneurs fail to receive the expected profit and the entrepreneurs' trust and confidence in the state reduces.

The head of City council J.L. classifies the violations into ill-intentioned violations and inadvertent violations. He indicates that in case of violations the commissioning party may fail to receive the best tender and fail to conclude the most advantageous contract.

Member of the Saeima Committee on Defence, Internal Affairs and Corruption Prevention, the former head of the Corruption Prevention and Combating bureau (KNAB) - A.L. states that violations in public procurements (including elaboration of the public procurement documentation in favour of the particular applicant, revealing of confidential information) are quite common and widespread. The expert expresses his concern about corruption offences that result in overpaid funds from the budget, the decrease of entrepreneurs' trust and confidence in the state and threats to fair competition.

The head of the Procurement Monitoring Bureau A.T. suggests that the number of complaints received by the Procurement Monitoring Bureau serves as an indicative of the frequency of violations taking place in the sphere of the public procurement. Generally it pertains to elaboration of procurement documentation containing discriminative norms. The complaint regarding the procurement documentation discharged by the Procurement Monitoring Bureau causes the necessity to suspend the announced procurement procedure and to eliminate violations. If violations have appeared at the tender evaluation stage, the commissioning party is obliged to revaluate the submitted tenders.

The head of the Latvian Builders Association M.N. indicates that a failure to prepare the procurement documentation in good quality causes financial damages to tax-payers.

V.K., senior researcher of the Latvia's leading corruption research centre, emphasizes procedural violations which result in reduction of the number of applicants. Which in its turn leads to increasing of commissioning party's costs, reduction of the quality of the procurement's subject matter, the commissioning party's failure to ensure the necessary control over quality of the contract execution?

When performing audits, the State Audit Office frequently concludes that funds have been spent not for the intended purpose, management of the funds have failed to be efficient and rational, no factors of quality have been defined for evaluation of the achieved results.

R.F., deputy director of the State Police names elaboration of public procurement documentation in favour of the particular entrepreneur as the basic problem of the field; she considers that violations take place in approximately $30 \%$ of procurements. This is the cause for the rise in prices and purchases of non-competitive products.

K.Z., the procurement expert claims that a prior agreement on public procurement results takes place in approximately $90 \%$ of procurements, therefore the quality of the public procurements is weak and hardships appear during execution of the contracts.

A.V., the deputy director of the Corruption Prevention and Combating Bureau distinguishes corruptive and non-corruptive offences and indicates that indiscriminately of kind of the offence they 


\section{Int. Conf. SOCIETY. HEALTH. WELFARE.}

distort the market, reduce competition and increase the price of the subject matter of the procurement. Moreover corruptive offences are interrelated with receiving of illegal income and money laundering.

In response to the question "Which fields of public procurement are exposed to violations most of all?" the experts shared a view that these are fields, where it is difficult to verify the pricing or check the actually achieved result, such as: construction (8 experts), IT - information technologies (5 experts), service procurements, security service, non-standard equipment, communication technologies, observation systems, public transport, consultations, public relations maintenance service.

Majority of the experts did not give definite answers to the question "How do you evaluate the spread of corruption in public procurements of Latvia?" Most often the experts substantiated their difficulties to give a definite answer by the absence of statistics or lack of scientific research in the field. Two experts, who gave their evaluation of level of corruption in percents, are convinced that the level of corruption in the field of public procurement is "35\%" and "more than 50\%".

In response to the question "Is corruption in public procurements usually caused by actions of individuals or by groups of persons?" expert opinions divided: 5 experts pointed out that corrupt actions are mostly performed by groups of persons; 2 experts shared the idea that corrupt activities are performed by individuals; 1 expert expressed the view concerning only the small procurements (corrupt actions are performed by individuals); 1 expert spoke only on big procurements (corrupt activities are performed by groups of persons), 1 expert did not give an answer to the question.

When discussing the motivation of officials for performing corrupt activities in public procurements, the experts mainly focused on greed of the officials, their wish to derive additional income, money, material wealth or personal gains. Three experts named political dependence as one of the motives for corruption. V.K., senior researcher of the corruption research centre provided the most extensive analysis of motivation for corruption of officials. The researcher indicated that besides such motive as the greed there may be other reasons for engaging of an official in corrupt activities, like - a wish to retain the power, gaining of funding for political parties, demonstrating obedience to the boss, in order to satisfy other passions.

In response to the question "What is the main motive for performing corrupt activities in public procurements?" the majority of experts indicated that the central motive is "to derive higher profit". Some experts expressed the belief that businessmen engage in corrupt activities in order to get status of the privileged and to develop their business; to obtain the procurement - for profit or to retain the business; to get the job and survive the crisis; to escape from bankruptcy.

Experts have different opinions on the issue- who usually exercise influence over decisions regarding the winner of the procurement most of all (procurement commission, administration of the commissioning party or businessmen): 4 experts emphasized the role of the commissioning party's administration; 2 experts indicated that the decision is influenced by all three subjects simultaneously; 1 expert stated that according to the norms of the Public Procurement Law, the decision on the winner of the procurement shall be taken by the procurement commission; 1 expert commented on businessmen influence; 1 expert suggested that unlawful decisions are taken mainly due to influence of administration of the commissioning party and businessmen; 1 expert did not comment on the matter.

In response to the question "Which are the most effective methods for prevention of corruption in public procurements?" the experts gave the following answers:

1. More effective appealing of decisions regarding smaller procurements; involving of an officer from the Corruption Prevention and Combating Bureau or the State Audit Office in work of the procurement commissions of big procurements; more effective and faster bringing to trial.

2. Standard forms for procurement documentation - samples for provisions and specifications of procurements.

3. Strict monitoring, precise procurement documentation, rotation of the le procurement commission members, centralization of procurements. 
4. Criminal liability, appropriate prison sentences and confiscation of property. It is necessary to achieve that the principle of unavoidability of punishment works.

5. Elaboration of Construction Cost Estimation Methodology, involving of civil engineers as experts in the work of procurement commissions, alterations to the legislation, improving of civic consciousness.

6. Effective investigation, holding administratively liable for offences, enhancement of competition, increasing certainty of punishment, increasing risks for corruptible persons.

7. Increasing of sentences or including of other methodological measures for preventing of corruption into the legal framework or enhancement of capacity of supervision authorities may create certain difficulties for making a corrupt deal; nevertheless it will be a struggle against the consequences.

8. More effective control to establish standards for the subject matter of the procurement.

9. To revise the legal order of the Public procurement law, increase liability of the procurement commission.

10. Broader competition, training of the officials, good salaries, dynamic purchasing system.

In response to the question "What liability shall be imposed on members of procurement commissions for offenses (if they do not pertain to bribe taking) in the field of public procurement?" most of the experts suggested to impose administrative or disciplinary liability. Sometimes they proposed intensification of one or another punishment by imposing financial sanctions. One of the experts suggested imposing of criminal liability for such offenses if they concern the largevalue procurements. It is worthy of note that two experts expressed the opinion that imposing of real punishments on members of the procurement commission would result in inability of the commissioning party to establish the procurement commission (employees of the commissioning party will refuse to work in procurement commissions).

While analysing the responses of experts to the question "What is your evaluation of activity of each subject in preventing and combating of corruption in the public procurements of Latvia (the Government, the Corruption Prevention and Combating Bureau, the State Audit Office, society of Latvia)?" the author has performed systematization and summarizing of data in the form of a table. Symbol " $n$ " designates a negative evaluation; "p" stands for a positive evaluation; "v" designates middling evaluation; "N/a" - no response:

It is apparent from this table that the majority of negative ratings was received by the society of Latvia, which according to some experts is characterised as "apathetic" and "relaxed". The relative majority of positive ratings were received by the Corruption Prevention and Combating Bureau.

\section{Discussion}

The author proceeds with the summary of expert suggestions for solving the problem of corruption in the sphere of public procurements:

1. I.S. expressed the belief that the main solutions could be: delegation of broader powers to the State Audit Office; more effective appealing of decisions regarding small procurements; involving of supervisors from the controlling services in work of procurement commissions of big procurements.

2. J.L. indicates that it is important to focus attention on such measures as: "zero" declaration; control over the legality of the income; solving of the money laundering problem; altering psychology of people; solving the issue of responsibility.

3. A.L. is convinced that a mechanism for protecting informers shall be envisaged; it is important to educate the society; commissioning parties shall minimize corruption risks by applying the principle of "four eyes" and performing of rotation. 


\section{Int. Conf. SOCIETY. HEALTH. WELFARE.}

4. A.T. indicated the necessity of developing of the good practice in procurements; ensuring holding administratively liable for committed offences; increasing "fear syndrome"; making blacklists of law breakers.

5. M.N. states, that "fear syndrome" shall be increased; quality of procurement commission shall be improved (specialization of commissions, involving of experts); centralization of procurements.

6. V.K. emphasizes the following: politicians shall understand that investing of illegal money flow into parties actually diminish their chances to obtain political power; more effective bringing to responsibility is necessary, as well as increasing certainty of punishment.

7. The State Audit Office focus attention on the fact that public procurements are performed in the environment with no opportunity to verify whether the planned result has been achieved and whether the investment corresponds to the result or not and to demand responsibility for the outcome. Policy of the state budget shall be altered from the policy of expenses to the resultsoriented policy. Such a system for management of state resources will promote understanding of responsible utilization of public funds and the achieved result, which in its turn will considerably diminish desire, motives and opportunities for deriving of undue benefit by means of public procurements.

8. R.F. holds a view that psychological and financial independence of officials shall be ensured.

9. K.Z. suggests systemic work in the field of corruption prevention and combating and to improve level of competence of procurement commissions and auditors.

10. A.V. has come to conclusion that it is necessary to find the mean between the bureaucracy and competition in public procurements; to solve the issue concerning state funding for political parties; to apply electronic and dynamic procurements more intensively; to ensure more effective operation of law enforcement bodies; to perform certification of public procurement executors.

The author comes forward with definite proposals for reducing the corruption level in the sphere of public procurement, by making appropriate alterations in the normative regulation. The author suggests that such steps could be - applying of the negotiation procedures to a lesser extent, giving a more explicit definition to evaluation criteria of economically advantageous tender (Krivinsh, 2012c), developing of electronic tendering system, centralization of purchases. Moreover, the author of the present article is convinced that the efficiency of prevention of corruption in public procurement would increase, if members of procurement commissions had a perfect knowledge of general legal principles, would accept their importance and would not tolerate the violation of these principles during implementation of the procurement procedure (Krivinsh, 2012d).

Having done the analysis of the EU directives and regulations concerning carrying out of public procurement as well as normative regulation of several countries regarding public procurement procedure, the author made a conclusion that the mechanism of carrying out of public procurement, if viewed from the perspective of fight against corruption, still has not been improved up to satisfactory level (Krivinsh, 2012e).

Audit of the normative acts regulating public procurement shall be performed in the member states of the European Union; implementation of the following principles will effectively prevent manifestations of corruption in the area of public procurement.

\section{Conclusions}

1. Representatives of all groups under study (commissioning parties, the Public Procurement Monitoring Bureau, the Corruption Prevention and Combating Bureau, the State Police of Latvia, entrepreneurs, researchers who study the issue of corruption, the State Audit Office, legislators, public procurement executors) indicate that the problem of corruption in the field of public procurement of Latvia is essential. 


\section{SHS Web of Conferences}

2. The experts share the view that violations take place in such fields of public procurement as construction, IT - information technologies, service procurements, security service, non-standard equipment, communication technologies, observation systems, public transport, consultations, public relations maintenance service.

3. In response to the question "How do you evaluate the spread of corruption in public procurements of Latvia?" the majority of the experts indicated the necessity of statistic data and scientific research in the field for giving an exact answer to the question. Unfortunately, the respondents could not substantiate their opinions with statistic data due to the absence of such information.

4. The majority of experts (7 out of 10) hold the view that the existing legal framework for performing of public procurements in Latvia is not sufficient for effective prevention of corruption risks. All experts (10) have suggested solutions for solving the problem of corruption in the field of public procurement.

\section{References}

[1] Krivinsh, A. (2012a). Professionalism of the public procurement practitioners from the perspective of fight against corruption. Humanities and Social Sciences Review, Vol. 01, number 04, 2012, (pp. 403-412), ISSN: 2165-6258.

[2] Krivinsh, A. (2012b). Uncorrupted public purchases as the factor of sustainability of business. In Proceedings of the Conference of the School of Business Administration Turība XIII International Scientific Conference Sustainable business under changing economic conditions Riga 30 March 2012, (pp. 233-241), ISSN 1691-6069.

[3] Krivinsh, A. (2012c). Proposals for preventing of corruption at the stage of elaboration of the procurement documents. In European Applied Studies: modern approaches in scientific researches, 1st International scientific conference (pp. 430-432). Stuttgart, ORT Publishing.

[4] Krivinsh, A. (2012d). The Prevention of Corruption in the Sphere of Public Purchases. In 4th International Interdisciplinary Scientific Conference "Society. Health. Welfare". 1st Conference of Speech Therapists (Rīga, November 22-23, 2012): Abstracts. (p.56). Rīga, Rīga Stradiņš University: ISBN 978-9984-793-19-1

[5] Krivinsh, A. (2012e). Potential features of the corrupted public procurements. In Scientific enquiry in the contemporary world: theoretical basics and innovative approach (pp. 65-68). FL, USA, L\&L Publishing, ISBN 978-1481822930. 